\title{
Media advocacy for sustainable water management in Africa: a study of Nigeria
}

\author{
C. C. Eze \\ Institute for Development Studies, University of Nigeria, \\ Enugu Campus, Nigeria
}

\begin{abstract}
Strategic uses of news created through mass media (tv, radio and newspapers) can promote public debate and generate community support for changes in community norms and policies on water challenges in Africa. Against this backdrop, the programme content of randomly selected radio stations within the south-eastern part of Nigeria within the last three years were content-analyzed to ascertain their degrees of focus on water and related issues. It was discovered that most of the radio stations studied devoted a negligible amount of their air time to water management. The study also established that members of the general public are the ultimate decision-makers and opinion leaders in our society. Attitudes, beliefs, norms, and practices are shaped by the dialogues that take place within families and the social networks we experience in our everyday lives. The study recommended leverageing on the potency of media advocacy in attaining the goals of sustainable safe water as key to healthy and prosperous communities.

Keywords: sustainable water management, strategic uses, public policy, media advocacy, Nigeria.
\end{abstract}

\section{Introduction}

Nigeria is allegedly rated as the third poorest country in the world in the provision of water for its citizens. With this rating, it is also placed among countries, which may not meet the United Nations (UN) Millennium Development Goal in water supply to its citizens due to poor governance (Okezi [1]). This is not unconnected to poor government policy over the years and the general attitude to public water supply. The laws on water management in the country are not being implemented. With constant increase in population, with no corresponding increase in drinking 
water the result is crisis. This informs Nigeria's rating as the third poorest country in terms of water supply after India and China (Okezi [1]).

The concept of media advocacy as a communication tool for some time has occupied the front burner in global public space. It could be seen as a tool for organizing a community through a strategic engagement of the media to promote the adoption of public policy. Similarly, Berkeley [2] considers media advocacy as the strategic use of mass media to support community in organizing to advance a social or public policy initiative.

In both instances the media operatives are seen as independent professionals who should be synergized into public policy in line with community aspirations. Hence media advocacy could play a leading role in ensuring that public interest and the interest of special or vulnerable groups are sufficiently represented in state water policy. Communication lies at the heart of human development. In this era of globalization, emerging and changing technologies in communication, information and social networking are transforming economic, social and cultural life as never before. The 'digital divide' is constantly narrowing as these technologies make information and communication easier, accessible and affordable.

This communication revolution has the capacity for empowerment, hence positioning people not just as media consumers but as communicators and agents of change capable of influencing policy that will address the looming crises in the water sector. Hence, media advocacy could also be seen as the process of disseminating policy-related information through the communications media, especially where the aim is to effect action, a change of policy, or to alter the public's view of an issue (Berkeley [2]).

\section{Theoretical framework}

This study will be anchored in the uses and gratification; and the individual differences theories of the media which state that members of the public make use of the media mainly due to the expected gratification from such usage. This gratification theory was developed in the 1940s when researchers became interested in the way people engaged in various forms of media behaviors. It is a theory that is audience-centered, asking what people do with the media. It states that audience derives level of satisfaction/reward from using the media. As Lazarsfeld and Stanton [3] noted ".... several typologies of mass media motives and functions have been formulated to conceptualize the seeking of gratifications as variable that intervene before media effects".

Recent studies have revealed that a variety of audience gratifications are related to a wide range of media effects. The uses and gratification theory reveals that people seek out and use the media to gain several gratifications. Individuals use the media, in how long they use the media and for what reasons. As a result, differences exist in the way individuals and group reacts to media messages. The expected gratification from the media might serve as the underpinnings for the engagement prescribed in the concept of media advocacy which is the subject of this paper, while individual's differences theory on the other hand explains the 
phenomenon. The uses and gratification stresses the various needs the media satisfies for the masses hence media content should carefully satisfy those needs (Eze [4]).

\subsection{Uses, Gratification theory and message reception}

People's communication behaviour is seriously affected or Influenced by those needs. Lazarsfeld and Stanton [3] summarized the uses and Gratification theory very masterly in one of their studies when they stated that the social and psychological origins of individual needs generate or lead to certain expectation from communication sources, media or channels of communication, and that these in turn lead to different patterns of media exposure which results in different need gratification and other consequences. Thorough understanding of patterns of media exposure and their role in the process of policy formulation is relevant for a meaningful constructive engagement of the media or media operatives in driving policy.

\subsection{Water management}

This refers to the allocation of limited water resources between agricultural, municipal and environmental uses and the full integration of supply, demand, water quality and ecological considerations. The goal of water management is to make it available and affordable for all purposes to promote good health, national welfare, food and self-sufficiency, as well as industrial growth (Okezi [1]). This understanding of water managements must have informed Orubu [5] when he emphasized that Government policy on the water resources sector has been hinged on the need for a sensible and comprehensive development of the country's water resources to provide safe drinking water for the populace in both urban and rural areas, make water available for agricultural development through irrigation schemes, as well as the generation of electricity along the country's main watersheds.

This crisis in the water sector is partly informed by quality of the water which is changed and affected by both natural processes and human activities. Generally natural water quality varies from place to place, depending on seasonal changes, climatic changes and with the types of soils, rocks and surfaces through which it moves. A variety of human activities e.g. agricultural activities, urban and industrial development, mining and recreation, potentially significantly alter the quality of natural waters, and changes the water use potential. The key to sustainable water resources management is, therefore to ensure that the quality of water resources are suitable for their intended uses, while at the same time allowing them to be used and developed to a certain extent. Effective management is the tool through which this is achieved.

This depletion of water resources also affects the supply for irrigation purposes resulting in unsustainable irrigation. This could be seen in the big dams and irrigation systems in developing countries which are less productive. This is often exacerbated when the control and management of such systems is not in the hands of the farmers who are the ultimate end users (Uprety [11]). 
The above scenario makes water reliability more vulnerable and less useful to farmers to intensify their cropping systems and adopt new technologies. This results in food shortage and many other consequences thus underscoring the importance of water as a key human resource.

Water quality management, therefore involves the maintenance of the fitness for use of water resources on a sustained basis, by achieving a balance between socio-economic development and environmental protection. The "business" of water quality management entails the ongoing process of planning, development, implementation and administration of water quality management policy, the authorisation of water uses that may have, or may potentially have, an impact on water quality, as well as the monitoring and auditing of the aforementioned (Toepfer [6]).

\subsection{Water crisis in Nigeria}

The existence and growth of urban cities demands clean reliable and adequate water supply. Consequently, economic and physical consideration on water supply should rank very high in urban planning. This is untrue in Nigeria. Firstly, the economic investment in water has been low comparatively to other infrastructure like roads bridges etc. In addition the economic cost of water to the users is low in relation to its domestic, industrial and commercial uses. Yet another issue that appears peculiar to Nigeria is the policy principle of the Federal Government which regards water supply as a social service (Oyebande [7]). The laws on water management however are not sufficiently implemented; this poor implementation informs the persistent crises in water management (Okezi [1]). This hinders rigorous economic analysis in water projects. Water is seen as a "free gift of nature". Consequently, since users do not pay the cost of harnessing and delivery of water then government is forced to bear the burden. Nigeria has enormous quantity of water resources, surface and underground, that requires a wellarticulated administrative structure that can manage the resources effectively. The present position of water supply in Nigeria is grossly inadequate. The Federal, States and Local Governments have over the years been intervening from time to time in terms of the provision of potable water to the people through the Federal Ministry of Water Resources, Petroleum Trust Fund (PTF), River Basin Authorities, DFRRI, National Water Supply Rehabilitation Project, National Borehole Programme and of course, the present government's Legislative Boreholes. Despite these efforts, potable water supply is still poor and grossly inadequate. In reality, the problem of water supply in Nigeria is enormous and can only be solved through properly coordinated approach so as to overcome the problem. According to Nwankwoala [8], water supply lies at the heart of development whether it is urban or rural. Water supply and development of any nation are continuing long-term process which requires careful planning and implementation geared towards achieving improved conditions of life. Consequently, there should be an overhaul/review of the existing water policy or a new national water policy that would involve a comprehensive hydro geological mapping of the country. 


\subsection{Water emergency in Africa}

On the other hand, water, poverty, and the environment are "intrinsically connected," and the development programs targeting them should be as well. Freshwater management challenges are increasingly common. Water has always been in adequate and rare commodity in Africa, whose rapidly growing population is now closing on the 800 million mark. And people here are not too fussy - any water, not just safe drinking water, will do to assuage their thirst. This lack of sufficient investment in public water supply in Africa is partly accountable to the high level of disease and poverty plaguing the continent (Kinoti [9]). Even in ancient times, African tribes used to fight over two things: water and cattle. History might be repeating itself as today's dwindling water resources may yet become the cause of crisis in the not too distant future.

At the moment many African countries are already faced with water scarcity, while another dozen will join this list in the next 25 years. Most Africans residing in rural areas use, on average, only 30 to 40 liters of water per day for domestic consumption, comparatively, the average U.S. consumer uses approximately 700 liters more, added to this about 300 million people in Africa still lack access to safe water (Toepfer [6]).

In sub-Saharan Africa, only 51 percent of the population has access to safe water. As the world is approaching the new millennium there is very real possibility of conflicts arising over natural resources, especially water. Yet another gloomy forecast is the estimate that, by the year 2025, almost one in two Africans will be living in an area of water scarcity or water stress. Scientists consider a country as facing water scarcity when fewer than 1,000 cubic meters of water are available per person per year. If fewer than 1,500 cubic meters of water are available per person per year that is referred to as water stress situation (Toepfer [6]).

\subsection{Media advocacy as a tool for water management}

While a strict definition of the concept of "media advocacy" may be limited to the strategic engagement of the mass media with regard to a policy initiative, "water management" on the other hand refers to the allocation of limited water resources between agricultural, municipal and environmental uses. Most urban centers in Nigeria lack save drinking water while the situation in the hinterland is not less gloomy as the available streams and brooks are hardly sufficient for humans and livestock. This underscores the need to effectively employ media advocacy as a communication tool to address the issues of water shortage in Nigeria.

Almost identical techniques are often used to encourage people to change behaviors as those directed towards influencing policy in water management. Media advocacy may be a single element of a specific campaign as well as an ongoing process and could be practiced at all levels, from national to community based campaigns. The ultimate targets of most media advocacy are politicians and other decision makers.

Media advocacy activities may be proactive and initiated, or they may be reactive. Reactive media advocacy involves taking action when required, 
especially when opponents are actively seeking to mislead, change the agenda, or divert attention to other issues. Media advocacy may be used for an ongoing campaign, perhaps to ensure that the need for a new policy in water management is kept on the political agenda.

Unlike public relations, advertising and other conventional communication tools, media advocacy emphasizes the constructive engagement of the media in championing one or several different goals in a planned or ongoing campaign. Certain information may be directed towards politicians and other opinion leaders whose support is needed to influence policy, while different but related information is aimed at current or potential target audience in order to avert the looming water crisis.

While the first is aimed at changing policy, the second seeks a behavior change. Both, however, share the overall goal of reducing the effect of phenomenon. In addition, an ongoing media advocacy program will also involve monitoring the media for misleading information put out by opponents with vested interests, and offering a prompt rebuttal.

Media advocacy is opportunistic. It exploits opportunities to use the media to convey information to large numbers of people, including special target groups. Workers in media advocacy have a good understanding of the operations of the mass media organizations; and they maintain good relationships with journalists, so as to enhance accessibility to relevant information and comments, as well as granting interviews and other assistance to journalists whenever necessary.

In contrast to the opportunistic and ongoing nature of media advocacy, paid media campaigns involve a more programmed delivery of education-oriented information, based on prior research, to specific target audiences. A publiceducation program may sometimes be supported by media advocacy, and vice-versa, but more often media advocacy is practiced on its own.

\subsection{Media advocacy and water management synergy}

Media advocacy for public water supply assumes that public water management advocates and journalists have something to offer each other, that there is a convenient symbiosis between their professions. Those on water have potential stories, and they want to get coverage for them as part of a campaign to bring about change, and journalists want new stories to fill time or editorial (i.e. non advertising) space in their media. Journalists often rely on specialists to help them gather, analyze, and comment on the material they use, and sometimes to suggest stories in the first place. Public water advocates either are such specialists, or they can provide access to them. They also provide ideas for new stories, new angles on old topics, and substantive information to help the journalist to produce an article or story.

Furthermore, water is a popular topic. Most people have a personal interest in anything affecting what is, as many see it, their most cherished gift - their health. Hence advocates of water therefore, by the very nature of their subject, have a head start when competing for the attention of journalists and for space in their media. 
Anyone can do media advocacy - from an individual or members of a small, community-based health organization to the largest state or federal government health agency. Few tools are needed other than a telephone and, preferably, personal computing equipment. In larger organizations, a press and public affairs department will usually carry out much of the work, involving others as required. In a smaller organization the functions may be part of an information officer's duties, or, in a very small unit, they may be performed by one person, perhaps the chief executive.

\subsection{Among the most common activities of media advocacy are the following:}

- Monitoring media for coverage of relevant topics; this service is often contracted to specialist agencies, or may be achieved via Internet-based services.

- Identifying and disseminating interesting news stories that support public health policies.

- Responding to journalists' inquiries and information requests.

- Supplying access to experts who can assist journalists.

- $\quad$ Preparing press releases and background papers.

- Arranging press conferences.

- Planning a media diary, including identification of special dates and opportunities.

- Responding to misleading or erroneous items in the media (Public Health Institute [10]).

Media advocacy also involves listing and training individuals to act as experts and spokespersons on particular issues. Searching for new angles on existing stories, and new spokespersons and organizations to back and to speak publicly for the policy - a wide variety of professionals and organizations may be recruited to support public policy.

\section{Methodology}

The programme content of four randomly selected radio stations across the country were analysed to ascertain the percentage of their news and current programme (on-air) time allotted to water and related issues over the last three years $(2009,2010,2011)$.Both public and privately owned radio stations were part of the study. The purpose is to establish the level of media engagement in water management campaigns in Nigeria in the years under review.

Tables 1, 2, and 3 below show selected radio stations coverage of water management in 2009, 2010, and 2011 respectively. 
Table 1: Selected radio stations coverage of water management in 2009.

\begin{tabular}{|l|l|l|l|l|l|}
\hline YEAR:2009 & $\begin{array}{l}\text { FRCN, } \\
\text { Enugu }\end{array}$ & $\begin{array}{l}\text { ESBS } \\
\text { Radio }\end{array}$ & $\begin{array}{l}\text { Ray } \\
\text { Power } \\
\text { FM }\end{array}$ & $\begin{array}{l}\text { Salt FM } \\
\text { Abakaliki }\end{array}$ \\
\hline No of stories & & 3 & 1 & 1 & - \\
\hline Duration(min) & & 1.5 & 1.5 & 2.5 & - \\
\hline \% Airtime & & 0.3 & 0.3 & 0.2 & - \\
\hline
\end{tabular}

Table 2: Selected radio stations coverage of water management in 2010.

\begin{tabular}{|l|l|l|l|l|l|}
\hline YEAR:2010 & $\begin{array}{l}\text { FRCN, } \\
\text { Enugu }\end{array}$ & $\begin{array}{l}\text { ESBS } \\
\text { Radio }\end{array}$ & $\begin{array}{l}\text { Ray } \\
\text { Power } \\
\text { FM }\end{array}$ & $\begin{array}{l}\text { Salt FM } \\
\text { Abakaliki }\end{array}$ \\
\hline No of stories & & 1 & 1 & - & 1 \\
\hline Duration(min) & & 1.8 & 2 & - & 3 \\
\hline$\%$ of Airtime & & 1.4 & 1.4 & - & 0.6 \\
\hline
\end{tabular}

Table 3: Selected radio stations coverage of water management in 2011.

\begin{tabular}{|l|l|l|l|l|l|}
\hline YEAR:2011 & & $\begin{array}{l}\text { FRCN, } \\
\text { Enugu }\end{array}$ & $\begin{array}{l}\text { ESBS } \\
\text { Radio }\end{array}$ & $\begin{array}{l}\text { Ray } \\
\text { Power } \\
\text { FM }\end{array}$ & $\begin{array}{l}\text { Salt FM } \\
\text { Abakaliki }\end{array}$ \\
\hline No of stories & & - & - & 1 & - \\
\hline Duration(min) & & - & - & 1.5 & - \\
\hline$\%$ of Airtime & & - & - & 0.3 & - \\
\hline
\end{tabular}

(Source: field survey 2009, 2010, 2011.)

\subsection{Findings}

According to the above table in the year 2009, it was only Federal Radio Corporation of Nigeria, Enugu(FRCN) that had up to (3) three news stories or 0.3 percent of total news time on water and related issues during the year under review. However Enugu State Broadcasting Service (ESBS) Radio and Ray Power FM Radio both had a story each or 0.2 and 0.3 percent while Salt FM Radio had none. The study further reveal that added together the four radio stations could only devote only about 0.8 percent of their news to water issues in year.

Similarly in 2010 FRCN and ESBS radio devoted one story each to water management. For FRCN the single story of 1.8 minutes amounted to $1.4 \%$ of total airtime while the same single story of 2 minutes airtime at ESBS amounted also to $1.4 \%$. However at Salt FM radio that devoted (1) one story of 3 minutes resulted to 0.6 percent of news time. This added together amounts to about 3.4 percent of news time that was allotted to water. However Ray Power had no story on water for the year.

Almost all the radio stations studied had no news report, current affairs or such programmes on water and related issues for 2011. The only exception was Raypower FM that had only one report lasting for about 1.5 minutes amounting to $0.3 \%$ of total air time for the year. 


\section{Conclusion}

This study shows clearly that a very negligible amount of airtime was allotted to water management and related issues during the year under review by all the radio stations studied. This is attributable to the lack of cohesion between the media and water resources managers in Nigeria. Media advocacy recommends a sustained engagement with the media this can only be achieved by synergizing with media professionals and winning their support and buy-in for the communication objective. The study also established that members of the general public are the ultimate decision-makers and opinion leaders in our society. Attitudes, beliefs, norms, and practices are shaped by the dialogues that take place within families and the social networks we experience in our everyday lives.

\section{References}

[1] Okezi G. Speech at conservation of water for human Development, organized by Benin-Owena River Basin Development Authority, Benin, Nigeria, 2012.

[2] Berkeley Media Studies Group; Media Advocacy, Center for Civic Partnership, 2008.

[3] Lazarsfeld B. \& Stanton E. The People's Choice: How the voter makes up his mind in presidential Campaign, New York: Duel Sloan and Pearce, 1949.

[4] Eze C.C. An Evaluation of communication strategies for malaria eradication amongst antenatal women in Enugu metropolis; IAABD conference proceedings; Casablanca-Morocco, pp. 563-573, 2012.

[5] Orubu C. O. Water resources, Environment and Sustainable Development in Nigeria; Journal of Human Ecology 19(3): pp. 169-181, 2006.

[6] Toepfer, K. United Nations Environment Program. Journal of Environmental Science and Technology, 2010.

[7] Oyebande, L. Appropriate administrative structures in harnessing water resources for sustainable growth in Nigeria. Journal of Mining and Geology, Vol. 42 (1), pp. 21-30, 2006.

[8] Nwankwoala H. O. Improving Water Resources management in Nigeria; Policy Imperatives and emerging realities. Scientia Africana, vol. 10 (No. 1) pp. 46-57, 2011.

[9] Kinoti, G. Hope for Africa, what the Christian can do. Nairobi: AISRB (African Institute for Scientific Research and Development), 1994.

[10] Public Health Institute, Media Advocacy: What is Media Advocacy? Center for Media Advocacy, 2010.

[11] Uprety R. Irrigation: 11 Thoughts on sustainable water use in agriculture, in Holly Young, Guardian Professional, 2013 www.stakeholdersdialogues.net Retrieved 16-09-2013. 